\title{
Studies on the Vibrio cholerae mucinase complex. I. Enzymic activities associated with the complex
}

\author{
D. E. S. STEWART-TULL, R. A. OLLAR and TAMARA S. SCOBIE* \\ Department of Microbiology Research Unit, Alexander Stone Building, Garscube Estate, Bearsden, Glasgow \\ G61 10H, and * Department of Biochemistry, University of Edinburgh Medical School, Hugh Robson Building, \\ George Square, Edinburgh EH8 9XD
}

Summary. Mucinase enzymes were isolated and partially purified from the culture fluid of Vibrio cholerae grown in proteose peptone-colostrum medium. The mucinase complex contained neuraminidase, endo- $\beta$ - $\mathrm{N}$-acetylhexosaminidase, nicotinamideadenine-dinucleotidase and proteinases. Traces of phospholipase activity were detected but the complex lacked aldolase activity.

\section{Introduction}

The mucinase activity of Vibrio cholerae was originally shown by the desquamation of guineapig ileal segments after exposure to culture filtrates for $3 \mathrm{~h}$ at $37^{\circ} \mathrm{C}$; this activity survived heating at $56^{\circ} \mathrm{C}$ for $30 \mathrm{~min}$ and was greater in the presence of $\mathrm{Ca}^{++}$ions (Burnet and Stone, 1947a). Burnet and Stone $(1947 b)$ also demonstrated the activity of another enzyme (receptor destroying enzyme) that removed the influenza virus receptor from erythrocytes; this enzyme was sensitive to heating at $56^{\circ} \mathrm{C}$ for $30 \mathrm{~min}$. It was identified subsequently as a sialidase (Heimer and Meyer, 1956) and finally as a neuraminidase (Gottschalk, 1957) which acted by removing the terminal neuraminic acid unit from a neuramin-lactose substrate by hydrolytic cleavage of the glycoside bond joining the keto-group of $\mathrm{N}$-acetylneuraminic acid to D-galactose or galactosamine.

Intestinal sialomucin may provide a physical barrier to $V$. cholerae colonisation of the intestinal epithelium but, as reviewed by Arbuthnott and Smyth (1979) and Savage (1980), enzymes of the mucinase complex could hydrolyse the mucus, create random tracks and enable the organisms to reach the columnar epithelial surface.

In a series of studies on the development of an acellular cholera vaccine, the mucinase enzymes were isolated and characterised, in view of their potential use as immunogens.

\section{Materials and methods}

\section{Bacterium}

Vibrio cholerae NCTC 10732, the classical biovar, Received 13 Dec. 1985; revised version accepted 18 Mar. 1986.
Inaba serovar was obtained from the National Collection of Type Cultures, Colindale, London.

\section{Medium for production of mucinase}

Bovine colostrum was obtained $24 \mathrm{~h}$ post-parturition at the Veterinary School experimental farm and kept at $-20^{\circ} \mathrm{C}$ until required. The colostrum $(1 \cdot 5 \mathrm{~L})$ was placed in dialysis tubing (Visking; diameter $7 \mathrm{~cm}$ ) and dialysed against $7 \mathrm{~L}$ of distilled water, saturated with chloroform to prevent bacterial contamination, for 7 days. The distilled water containing dialysed substances was transferred to a 5-L pressure vessel (Millipore), aerated for $2 \mathrm{~h}$ with sterile filtered air to remove traces of chloroform and subsequently filtered through a $0.45-\mu \mathrm{m}$ membrane in a Millipore filter holder (diameter $142 \mathrm{~mm}$ ) under nitrogen pressure into a $15-\mathrm{L}$ fermenter vessel containing meat peptone at a final concentration of $1 \% \mathrm{w} / \mathrm{v}$.

Meat peptone ( $150 \mathrm{~g}$; Gibco-Europe) was dissolved in $7.5 \mathrm{~L}$ of distilled water, placed in the fermenter vessel and sterilised by autoclaving at $121^{\circ} \mathrm{C}$ for $1 \mathrm{~h}$. Glycerol (BDH, Poole, Dorset) was sterilised at $121^{\circ} \mathrm{C}$ for $30 \mathrm{~min}$ and $112 \mathrm{ml}$ was added aseptically to the fermenter vessel. After the addition of the colostrum dialysate, the volume was adjusted to $14.75 \mathrm{~L}$ with sterile distilled water.

The large-scale batch fermenter was primed with a $250-\mathrm{ml}$ inoculum of an overnight culture of $V$. cholerae NCTC 10732 grown in proteose peptone (GibcoEurope) $2 \% \mathrm{w} / \mathrm{v}$. The fermenter (L. H. Engineering Ltd, Stoke Poges, Bucks) was run at $37^{\circ} \mathrm{C}$ with an air-flow of $5 \mathrm{~L} / \mathrm{min}$, stirring at $300 \mathrm{rpm}$ and with automatic dosing of $1 \% \mathrm{v} / \mathrm{v}$ Antifoam C Emulsion (Sigma Chemical Co., Poole, Dorset). After $24 \mathrm{~h}$ the organisms were killed in situ with merthiolate $0.01 \%$ (Sigma) or by increasing the temperature to $60^{\circ} \mathrm{C}$ for $2 \mathrm{~h}$. The cells were removed from the culture fluid by centrifugation at $9000 \mathrm{~g}$ for 15 $\min$.

\section{Partial purification of mucinase}

Methanol $(1.5 \mathrm{~L})$ cooled to $-30^{\circ} \mathrm{C}$ was added in 
$300-\mathrm{ml}$ volumes/h to $1 \mathrm{~L}$ of the culture supernate and left at $4 \mathrm{C}$ for $48 \mathrm{~h}$. The precipitate was harvested by centrifugation at $12000 \mathrm{~g}$ for $15 \mathrm{~min}$. The pellets so obtained from the $15 \mathrm{~L}$ of culture supernate were resuspended in $100 \mathrm{ml}$ of $0.05 \mathrm{M}$ sodium acetate buffer, $p \mathrm{H} \mathrm{5.5}$, and dialysed against the same buffer for $2-3$ days at $4 \mathrm{C}$. The retentate was centrifuged at $12000 \mathrm{~g}$ for $15 \mathrm{~min}$ and the supernate, containing crude mucinase, was concentrated with polyethylene glycol 4000 (Carbowax, BDH) to a final volume of $50 \mathrm{ml}$.

\section{Gel filtration of crude enzyme concentrate}

The most suitable grade of Sephadex for the partial purification of the crude mucinase was G100. The beads were suspended in $0.05 \mathrm{~m}$ sodium acetate buffer at $p \mathrm{H} 5.5$ and poured into an $80 \times 1.5 \mathrm{~cm}$ column. The crude concentrate $(2 \mathrm{ml})$ was filtered through the column with the same buffer as eluate, at a flow rate of $0.8 \mathrm{ml} / \mathrm{min}$. The absorption value at $280 \mathrm{~nm}$ and the Lowry protein value were determined for each $2-\mathrm{ml}$ column fraction. Thiobarbituric acid and methoxyphenol-neuraminate assays were also done on each fraction. The fractions within the peak of enzyme activity were pooled. concentrated with Carbowax to $2 \mathrm{ml}$ and stored at $-20 \mathrm{C}$. The neuraminidase-containing preparations were designated $\mathrm{G} 100 / \mathrm{N}$.

\section{Estimation of protein}

The protein content of the partially purified mucinase complex was determined by a Lowry assay with bovine serum albumin as standard (Lowry et al.. 1951) or by a modification of the microbiuret method of Levin and Brauer (1951) with ovalbumin as the standard. In the latter test, mucinase samples $(1 \mathrm{ml})$ were mixed with $0.3 \mathrm{ml}$ of $3 \mathrm{~N} \mathrm{NaOH}$ and heated at $100 \mathrm{C}$ for $5 \mathrm{~min}$. The mixtures were cooled to room temperature and $0.2 \mathrm{ml}$ of $\mathrm{CuSO}_{4} \cdot 5 \mathrm{H}_{2} \mathrm{O} 2.5 \% \mathrm{w} / \mathrm{v}$ was added. After $5 \mathrm{~min}$, the mixtures were centrifuged at $1200 \mathrm{~g}$ and the absorption values at $555 \mathrm{~nm}$ of the supernates were recorded.

\section{Determination of neuraminidase activity.}

(a) Thiobarbituric acid (TBA) assay (Warren. 1959). Bovine submaxillary mucin $(20 \mathrm{mg})$ was dissolved in $5 \mathrm{ml}$ of $0.05 \mathrm{M}$ sodium acetate buffer. $p \mathrm{H} 5.5$, containing $\mathrm{CaCl}_{2}$ $0.1 \% \mathrm{~W} / \mathrm{V}$ and $\mathrm{NaCl} 1 \% \mathrm{~W} / \mathrm{v}$. The $V$. cholerae neuraminidase as the $\mathrm{G} 100 \mathrm{~N}$ fraction $(0.1 \mathrm{ml})$ was added to $0.4 \mathrm{ml}$ of the solution of bovine submaxillary mucin. The volume was adjusted to $1 \mathrm{ml}$ with buffer and the mixture was incubated at $37^{\circ} \mathrm{C}$ for $30 \mathrm{~min}$. Subsequently, $1 \mathrm{ml}$ of phosphotungstic acid $(5 \mathrm{~g}$ in $100 \mathrm{ml}$ of $2 \mathrm{~N} \mathrm{HCl})$ was added and the mixtures were centrifuged at $1200 \mathrm{~g}$ for $10 \mathrm{~min}$. A $0 \cdot 5-\mathrm{ml}$ volume of each supernate was removed and added to $0.1 \mathrm{ml}$ of periodate solution $(4.27 \mathrm{~g}$ sodium periodate in $38.3 \mathrm{ml}$ distilled water and $61.7 \mathrm{ml}$ phosphoric acid). After $20 \mathrm{~min}$ at room temperature. $1 \mathrm{ml}$ of arsenite solution $\left(\mathrm{Na}_{2} \mathrm{SO}_{4} 17.75 \mathrm{~g}\right.$ in $250 \mathrm{ml}$ of distilled water with $5 \mathrm{ml}$ of $5 \mathrm{~N} \mathrm{H}_{2} \mathrm{SO}_{4}$ and $25 \mathrm{~g}$ of sodium arsenite) was added and the mixtures were shaken until unreacted iodides were removed, as indicated by loss of yellow colour. Thiobarbituric acid solution $(3 \mathrm{ml}$ of solution containing $4.5 \mathrm{~g}$ of twice-crystallised thiobarbituric acid in $750 \mathrm{ml}$ of $0.5 \mathrm{M} \mathrm{Na}_{2} \mathrm{SO}_{4}$ ) was added. Tubes containing the reaction mixtures were placed in a heating-block at $100 \mathrm{C}$ for $15 \mathrm{~min}$ before cooling to room temperature. Re-distilled cyclohexanone $(4.6 \mathrm{ml})$ was added to each tube, the mixtures were shaken and centrifuged at $1200 \mathrm{~g}$ for $3 \mathrm{~min}$ and finally the absorption value at $549 \mathrm{~nm}$ of the organic phase was recorded.

The amount of neuraminic acid (NANA) released from the mucin was determined by reference to a standard curve of neuraminic acid. Positive controls were $V$. cholerae neuraminidase (Koch Light) and Clostridium perfringens neuraminidase (Sigma). The activity of enzyme preparations was calculated on the basis that 1.0 International Unit (IU) liberates $309 \cdot 3 \mu \mathrm{g}$ of NANA/min.

(b) Methoxyphenol-neuraminate (MPN) assay of Palese et al. (1973). The substrate in this assay, kindly provided by the Research Resources Branch, NIAID, Bethesda, MD, USA, was 2-( $3^{\prime}$ methoxy-phenol)- $\mathrm{N}$-acetyl- $\alpha$ neuraminic acid; the stock substrate solution contained $50 \mathrm{mg}$ in $11.82 \mathrm{ml}$ of $0.1 \mathrm{M}$ sodium phosphate buffer, $p \mathrm{H} 5.9$. Neuraminidase-containing $\mathrm{G} 100 / \mathrm{N}$ fractions $(0.1 \mathrm{ml})$ were mixed with $0.1-\mathrm{ml}$ volumes of $0.1 \mathrm{M}$ sodium phosphate buffer, $p \mathrm{H} \mathrm{5.9}$, in the presence of $2 \mathrm{mM} \mathrm{CaCl}_{2}$ and warmed at $37^{\circ} \mathrm{C}$ for $3 \mathrm{~min}$ before the addition of $0.1 \mathrm{ml}$ of the stock substrate solution. The mixtures were incubated at $37^{\circ} \mathrm{C}$, and the reaction was stopped after $30 \mathrm{~min}$ by the addition of $25 \mu \mathrm{l}$ of $\mathrm{M}$ disodium ethylene diamine tetraacetic acid (BDH). The mixtures were kept in an ice-bath for $30 \mathrm{~min}$ and $0.2 \mathrm{ml}$ of freshly prepared and filtered diazonium salt of 4-amino-2,5-dimethoxy-4'nitroazobenzene (Koch-Light Laboratories; diazonium salt ADNB $6.0 \mathrm{mg}$ in $1 \mathrm{ml}$ of $0.4 \mathrm{M}$ sodium phosphate buffer, $p \mathrm{H} \mathrm{7.0)}$ ). After $30 \mathrm{~min}, 4 \mathrm{ml}$ of $0.5 \mathrm{~N} \mathrm{NaOH}$ was added to dissolve the precipitate, the tubes were centrifuged at $1200 \mathrm{~g}$ for $3 \mathrm{~min}$ and the absorption values of the supernates at $580 \mathrm{~nm}$ were recorded. The amount of methoxyphenol liberated was determined from a standard curve; 1 IU of neuraminidase liberates $121 \cdot 14 \mu \mathrm{g}$ of methoxyphenol $/ \mathrm{min}$. A conversion factor of 0.401 was used to calculate the amount of NANA (in $\mu \mathrm{g}$ ) released from the substrate.

\section{Proteinase activity}

The digestion of casein with trypsin as standard (Kunitz, 1947) was the method used. The partially purified $V$. cholerae mucinase $\mathrm{G} 100 / \mathrm{N}(1 \mathrm{ml})$ was added to $1 \mathrm{ml}$ of casein solution ( $1 \mathrm{~g}$ of casein, Hammarsten grade, $\mathrm{BDH}$. dissolved in $0.1 \mathrm{M}$ sodium phosphate buffer, $p \mathrm{H} 7 \cdot 6$, to a final volume of $100 \mathrm{ml}$ ) and incubated at $37 \mathrm{C}$ for $30 \mathrm{~min}$. The reaction was stopped by adding $3 \mathrm{ml}$ of trichloroacetic acid $5 \% \mathrm{w} / \mathrm{v}$ and incubating at $45 \mathrm{C}$ for $15 \mathrm{~min}$. Undigested casein was removed by centrifugation at $1200 \mathrm{~g}$ for $10 \mathrm{~min}$ and the absorption 
values of the supernates at $280 \mathrm{~nm}$ were recorded. Proteinase activity was determined from the standard plot for trypsin.

\section{Phospholipase $C$ activity (Boehringer, Mannheim $\mathrm{GmbH}, 1983)$}

The lecithin substrate used in this assay was prepared by a modification of the method of Pangborn (1951) and was described in detail by Stewart-Tull et al. (1978). The partially purified $V$. cholerae fraction $(20 \mu 1)$ was added

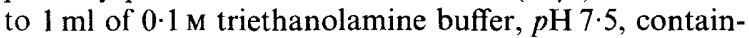
ing $20 \mathrm{mM} \mathrm{CaCl}, 1 \mathrm{ml}$ of freshly prepared lecithin suspension $(20 \mathrm{mg} / \mathrm{ml}$ in distilled water), $50 \mu \mathrm{l}$ of lipase (ex Rhizopus arrhizus $10 \mathrm{mg} / \mathrm{ml}$ in $3.2 \mathrm{M}$ ammonium sulphate, EC. 3.1 .1 .3 ) and $0.5 \mathrm{ml}$ of distilled water. After $15 \mathrm{~min}$ at $37^{\circ} \mathrm{C}$ the reaction was stopped with $0.3 \mathrm{ml}$ of $1.5 \mathrm{M}$ trichloroacetic acid. The mixtures were heated at $100^{\circ} \mathrm{C}$ for $2 \mathrm{~min}$, cooled and centrifuged at $1200 \mathrm{~g}$ for $5 \mathrm{~min}$. The supernate $(0.25 \mathrm{ml})$ was pipetted into a cuvette with $2.5 \mathrm{ml}$ of $0.3 \mathrm{M}$ triethanolamine buffer, $p \mathrm{H} 7 \cdot 6$, containing $4 \mathrm{~mm}$ magnesium sulphate, $0.15 \mathrm{ml}$ of a solution containing $32 \mathrm{~mm}$ ATP, $6 \mathrm{~mm} \mathrm{NADH}$ and $45 \mathrm{~mm}$ PEP, $0.01 \mathrm{ml}$ of lactate dehydrogenase $5.0 \mathrm{mg} / \mathrm{ml}$ in $3.2 \mathrm{M}$ ammonium sulphate and $0.01 \mathrm{ml}$ of pyruvate kinase $2 \mathrm{mg} / \mathrm{ml}$ in $3.2 \mathrm{M}$ ammonium sulphate. The reagents were mixed in the cuvette and the absorption value at $340 \mathrm{~nm}$ was recorded, $A_{1}$. Finally, $0.04 \mathrm{ml}$ of glycerol kinase $(1 \mathrm{mg} / \mathrm{ml}$ in $3.2 \mathrm{M}$ ammonium sulphate) was added and after $10 \mathrm{~min}$ the absorption value at $340 \mathrm{~nm}$ was recorded, $\mathrm{A}_{2}$. The relative phospholipase $\mathrm{C}$ activity $\Delta \mathrm{A}$ was equal to $\mathrm{A}_{1}-\mathrm{A}_{2}$ and was quantified by reference to a standard plot of values obtained with Bacillus cereus phospholipase C (Boehringer, EC 3.1.4.3, $2 \mathrm{mg} / \mathrm{ml}$ in $3 \cdot 2 \mathrm{M}$ ammonium sulphate). One IU of phospholipase C hydrolyses $1 \mu$ mole of lecithin/min.

\section{Endoglycosidase activity (Dubois et al., 1956; Chien et al., 1975)}

Streptomyces griseus endoglycosidase (Seikagaku Kogyo Co. Ltd, Tokyo, Japan; $\mathbf{0} \cdot 1$ unit of freeze-dried enzyme was dissolved in $100 \mu$ l of distilled water) was compared with the $V$. cholerae partially purified mucinase against ovalbumin substrate (Sigma grade V; $2 \mathrm{mg}$

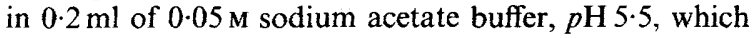
contained sodium dodecyl sulphate $0 \cdot 5 \% \mathrm{w} / \mathrm{v}$ ).

The G100/N enzyme sample $(20 \mu \mathrm{l})$ or the $S$. griseus endoglycosidase ( $20 \mu \mathrm{l}$ of stock solution $2 \mu \mathrm{l}$ in $100 \mu \mathrm{l}$ of $0.1 \mathrm{M} \mathrm{NaCl}$ containing bovine serum albumin $0.1 \% \mathrm{w} / \mathrm{v}$ ) was added to $0.5 \mathrm{ml}$ of ovalbumin substrate and incubated for $1 \mathrm{~h}$ at $37^{\circ} \mathrm{C}$. An equal volume of cold trichloroacetic acid $12.5 \% \mathrm{w} / \mathrm{v}$ was added to stop the reaction and after $15 \mathrm{~min}$ at $0^{\circ} \mathrm{C}$ the mixtures were centrifuged for $30 \mathrm{~min}$ at $35000 \mathrm{~g}$. Samples $(0 \cdot 2 \mathrm{ml})$ of the clear supernate were assayed for neutral sugar by the phenol sulphuric acid method; $50 \mu \mathrm{l}$ of phenol $80 \% \mathrm{w} / \mathrm{v}$ and $0.5 \mathrm{ml}$ $36 \mathrm{~N} \mathrm{H}_{2} \mathrm{SO}_{4}$ (Analar) were added and after $30 \mathrm{~min}$ at room temperature the absorption values at $490 \mathrm{~nm}$ were recorded. The endoglycosidase activity of the G100/N fraction was measured by the release of neutral sugar relative to glucose. The units of endoglycosidase activity were calculated from a standard curve of glucose released from ovalbumin substrate against different concentrations of commercial enzyme.

\section{$S D S-P A G E$}

The method used for sodium dodecyl sulphate polyacrylamide gel electrophoresis (SDS-PAGE) was based on that of Laemmli (1970) as modified by Ames (1974). The separating gel $(11 \% \mathrm{w} / \mathrm{v})$ contained $\mathrm{N}, \mathrm{N}^{\prime}$ bis-acrylamide (acrylamide $30.0 \mathrm{~g}$; N,N'methylene bis-acrylamide $0.8 \mathrm{~g}$; water to $100 \mathrm{ml}) 36.7 \mathrm{ml} ; 1 \mathrm{M}$ Tris $/ \mathrm{HCl}$ buffer, $p \mathrm{H}$ $8.8,37.5 \mathrm{ml} ; \operatorname{SDS} 20 \% \mathrm{w} / \mathrm{v}, 0.5 \mathrm{ml} ; \mathrm{N}, \mathrm{N}, \mathrm{N}^{\prime}, \mathrm{N}^{\prime}$-tetramethylethylenediamine (TEMED; Sigma), $25.0 \mu \mathrm{l}$; ammonium persulphate $0.8 \% \mathrm{w} / \mathrm{v}, 10.0 \mathrm{ml}$; and water, $15.3 \mathrm{ml}$. The stacking gel $(5 \%)$ contained $16.7 \mathrm{ml}$ of the $\mathrm{N}, \mathrm{N}^{\prime}$ bis-acrylamide solution; $0.5 \mathrm{M}$ Tris $/ \mathrm{HCl}$ buffer, $p \mathrm{H} 6.8,25.0 \mathrm{ml}$; SDS $20 \% \mathrm{w} / \mathrm{v}, 0.5 \mathrm{ml}$; TEMED $25 \mu$; ammonium persulphate $0.8 \% \mathrm{w} / \mathrm{v}, 10 \mathrm{ml}$; and water, $47.8 \mathrm{ml}$.

Each sample was mixed with an equal volume of solubilising buffer (sodium dodecyl sulphate $20 \% \mathrm{w} / \mathrm{v}, 20 \mathrm{ml}$; $0.5 \mathrm{M}$ Tris $/ \mathrm{HCl}$ buffer, $p \mathrm{H} 6.8,25 \mathrm{ml} ; \beta$-mercaptoethanol, $10 \mathrm{ml}$; glycerol, $20 \mathrm{ml}$; bromophenol blue $0.1 \% \mathrm{w} / \mathrm{v}$, $2.0 \mathrm{ml}$; water, $23 \mathrm{ml}$ ) and heated at $100^{\circ} \mathrm{C}$ for $5 \mathrm{~min}$. Samples of $75 \mu \mathrm{l}$ volume were run for approximately $3 \mathrm{~h}$ at $15 \mathrm{~mA}$ in a Shandon analytical slab PAGE outfit with a Tris/glycine/SDS buffer $(3.03 \mathrm{~g}, 14.4 \mathrm{~g}, 0.1 \mathrm{~g}$ respectively in $100 \mathrm{ml}$ of water). Protein bands were visualised by staining for $1 \mathrm{~h}$ with Coomassie brilliant blue (Sigma) $1.25 \mathrm{~g}$ in $454 \mathrm{ml}$ of methanol plus $46 \mathrm{ml}$ of glacial acetic acid (Analar; BDH)). Gels were destained in methanol, $50 \mathrm{ml}$ : acetic acid, $75 \mathrm{ml}$ : water, $875 \mathrm{ml}$.

\section{ADP-ribosylating activity}

ADP-ribosylation was measured by the indirect method of Tait and Nassau (1984). Each assay was done with a mixture (total volume $100 \mu \mathrm{l}$ ) containing $200 \mathrm{~mm}$ potassium phosphate $\left(\mathrm{KH}_{2} \mathrm{PO}_{4}-\mathrm{K}_{2} \mathrm{HPO}_{4}\right)$, pH 6.5, $20 \mathrm{~mm}$ dithiothreitol, $0.2 \mathrm{~mm}$ NAD (Grade 1, Boehringer-Mannheim) containing $2 \times 10^{5} \mathrm{cpm}\left[4-{ }^{3} \mathrm{H}\right]-$ NAD $(1.01 \mathrm{mCi} / \mathrm{mmol}$; Amersham International $), 2.0 \mathrm{~mm}$ 10-( $\rho$-methoxyphenyl methyl decanyl)-guanidine; kindly provided by Glaxo Group Research Ltd, Greenford, Middlesex, and $10.0 \mu \mathrm{g}$ of cholera toxin (List Biochemical Laboratories, CA, USA) or the experimental sample to be assayed. The mixture was incubated for $30 \mathrm{~min}$ at $37^{\circ} \mathrm{C}$; after this time, the reaction was stopped by dilution with $1 \mathrm{ml}$ of distilled water.

$\left[{ }^{3} \mathrm{H}\right]$-nicotinamide was separated from the unreacted $\left[4-{ }^{3} \mathrm{H}\right]-\mathrm{NAD}$ by ion-exchange chromatography on $0.5 \times 1.0$ columns of QAE-25 Sephadex. The diluted reaction mixture was loaded on to the column and the $\left[{ }^{3} \mathrm{H}\right]$-nicotinamide was eluted with $3 \mathrm{ml}$ distilled water into scintillation vials containing $15 \mathrm{ml}$ of emulsifying 


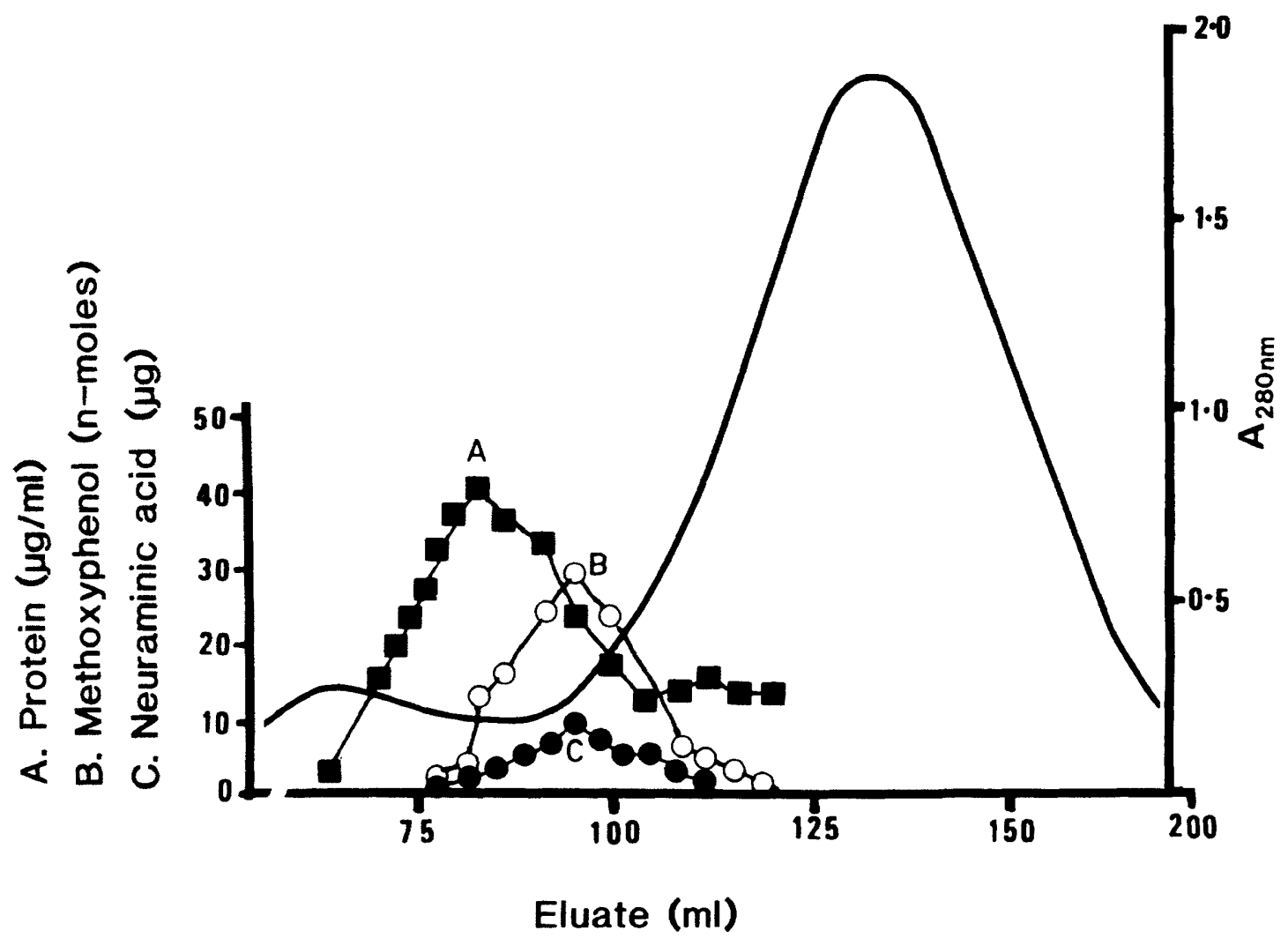

Fig. 1. Elution profile of $V$. cholerae methanolic precipitate of culture fluid separated on Sephadex Gl00 measured by absorption at $280 \mathrm{~nm}$. The maximum neuraminidase activity associated with the mucinase complex was detected in the interpeak fractions between peaks 1 and 2 by both the MPN-assay (curve B, - $-O$ ) and the thiobarbituric acid assay (curve C, - - ) The Lowry protein content of the interpeak fractions is shown in curve $A(\square-\square)$

scintillant (Optiphase Safe. LKB). The unreacted NAD remained on the column and was eluted with $5 \mathrm{ml}$ of $1 \mathrm{M}$ $\mathrm{HCl}$. followed by $10 \mathrm{ml}$ of water.

Determination of cholera enterotoxin by a bovine brain ganglioside ELISA assay.

Plates were coated, $50 \mu \mathrm{l} /$ well, with bovine brain gangliosides (Type III: Sigma) $2 \mu \mathrm{g} / \mathrm{ml}$ in phosphate-bufferedsaline (PBS). After $16 \mathrm{~h}$ at $37 \mathrm{C}$. free ganglioside was removed by washing three times with PBS. Free binding sites were blocked with $100 \mu \mathrm{l} /$ well of BSA $2 \% \mathrm{w} / \mathrm{V}$ in PBS; the plates were left for $30 \mathrm{~min}$ at $37 \mathrm{C}$ and then washed again with PBS. Cholera enterotoxin (LIST Biochemical Laboratories, CA. USA) or the test samples were added. $50 \mu 1$ in PBS, incubated for $1 \mathrm{~h}$ at $37 \mathrm{C}$ and washed with PBS containing $0.05 \% \mathrm{v} / \mathrm{v}$ Tween 20 . Rabbit anti-cholera toxin immunoglobulin was kindly donated by Dr M. Sowa, Glaxo Group Research Ltd. The presence of bound cholera enterotoxin was determined by the sequential addition of $50 \mu$ of a 1 in 200 dilution of rabbit anti-cholera toxin, $50 \mu \mathrm{l}$ of anti-rabbit immunoglobulin-alkaline phosphatase conjugate and
$50 \mu$ of $p$-nitrophenylphosphate (Sigma) with incubation at $37 \mathrm{C}$ for $\mathrm{l} \mathrm{h}$ and washing in PBS between each step. Absorbance was read at $405 \mathrm{~nm}$ and the concentration of enterotoxin $(\mu \mathrm{g} / \mathrm{ml})$ was determined from a standard curve.

\section{Results}

Large scale batch production of mucinase enzyme

With the proteose peptone-colostrum medium of Ada et al. (1961), reasonable yields of neuraminidase were obtained from $V$. cholerae. On average, for each $15 \mathrm{~L}$ batch, 180 enzyme units were produced. The enzyme was partially purified from the culture supernate by methanol precipitation at 4 C. The resultant precipitate was filtered through Sephadex $\mathrm{G} 100$ with $0.05 \mathrm{M}$ sodium acetate buffer. A plot of the $A_{280 \mathrm{~nm}}$ values of the column fractions showed two peaks (fig. 1). The major and second peak contained some brown pigment extracted from the spent medium and analysis of individual column fractions showed that the peak contained 
0.78 international milliunits (ImU) of neuraminidase $/ \mathrm{mg}$ of protein. The minor peak contained $5.4 \mathrm{ImU}$ of neuraminidase $/ \mathrm{mg}$ of protein. However, it became apparent that there was a peak of enzyme activity between these two peaks which contained $9.3 \mathrm{ImU}$ of neuraminidase $/ \mathrm{mg}$ of protein. This result was consistently obtained and therefore the inter-peak fractions were routinely collected as the partially purified mucinase. The neuraminidase peak fractions from six column separations were pooled to provide a sufficient supply of mucinase, designated as $\mathrm{G100/N}$.

These findings were supported by SDS-PAGE analyses of (a) the methanolic precipitate containing crude mucinase complex, (b) pooled peak fractions from the Sephadex G100 column and (c) the inter-peak, pooled fractions from the G100 column that showed maximum neuraminidase activity. The result shown in fig. 2 indicated that there were three major bands shared in these preparations, together with several minor bands. Partial purification by Sephadex filtration removed a large amount of low-molecular-weight material, probably medium constituents. It was apparent that the mucinase consisted of a mixture of proteins with or without enzymic activity. Further attempts at purification by ion-exchange chromatography produced fractions with much lower neuraminidase activity and were not pursued.

The protein content of the Sephadex G100/N preparation varied from batch to batch when determined either by the Lowry or by the microbiuret method. The range was $37-562 \mu \mathrm{g}$ of protein $/ \mathrm{ml}$ by the former method and $32 \cdot 8-319 \mu \mathrm{g} / \mathrm{ml}$ by the latter method. As shown in the table there was reasonable agreement between the values obtained by the two methods.

\section{Enzymic activities detected in the mucinase complex}

Neuraminidase. The level of neuraminidase activity in the partially purified preparations G100/ $\mathrm{N}_{1}-\mathrm{N}_{4}$ from the culture fluid of $V$. cholerae grown in the colostrum-proteose peptone medium were in the range $30-55 \mathrm{ImU} / \mathrm{mg}$ of protein, as determined from the release of nanomoles of $\mathrm{N}$-acetyl-neuraminic acid from bovine submaxillary mucin detected in the TBA assay (table). The comparative range of neuraminidase levels was $81-740 \mathrm{ImU} / \mathrm{mg}$ of protein when the more specific MPN assay was used.

Endoglycosidase. The $\mathrm{G} 100 / \mathrm{N}_{1}-\mathrm{N}_{4}$ preparations contained levels of endoglycosidase which varied from 0.62 enzyme units (EU)/mg protein for $\mathrm{G} 100 /$ $\mathrm{N}_{1}$ to $10.88 \mathrm{EU} / \mathrm{mg}$ of protein for $\mathrm{G} 100 / \mathrm{N}_{4}$ (table).

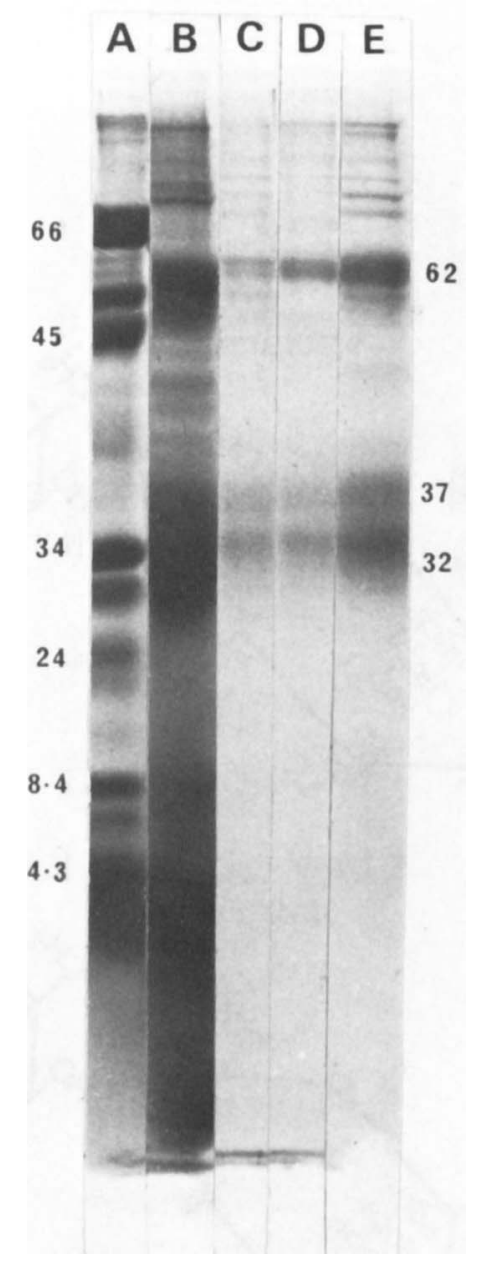

Fig. 2. SDS-PAGE analysis of $V$. cholerae culture fluid fractions. A, Standard protein mixture; B, crude methanolic precipitate of $V$. cholerae culture fluid; C, peak 1 Sephadex G100; D, interpeak fractions; E, peak 2 Sephadex G100. Estimated molecular weights $\left(10^{3}\right)$ shown against standard proteins.

Proteinase. All the $\mathrm{G} 100 / \mathrm{N}$ preparations with the exception of $\mathrm{G} 100 / \mathrm{N}_{4}$ contained proteinase equivalent to micrograms of trypsin; the values were in the range $37 \cdot 0-56.5$ (table). In addition, the methanolic precipitate of the culture fluid decreased the ADP-ribosylating activity of pure cholera enterotoxin after incubation for $30 \mathrm{~min}$ at $37^{\circ} \mathrm{C}$. The activity ratio of treated cholera toxin: untreated toxin, was 0.64 for the methanolic precipitate and 0.68 for $\mathrm{G} 100 / \mathrm{N}_{2}$ mucinase complex.

Phospholipase $C$. The levels of phospholipase $\mathrm{C}$ were calculated relative to the activity of $B$. cereus enzyme; the calculated values were not significant and were in the range 0.0014-0.014 IU (table). 


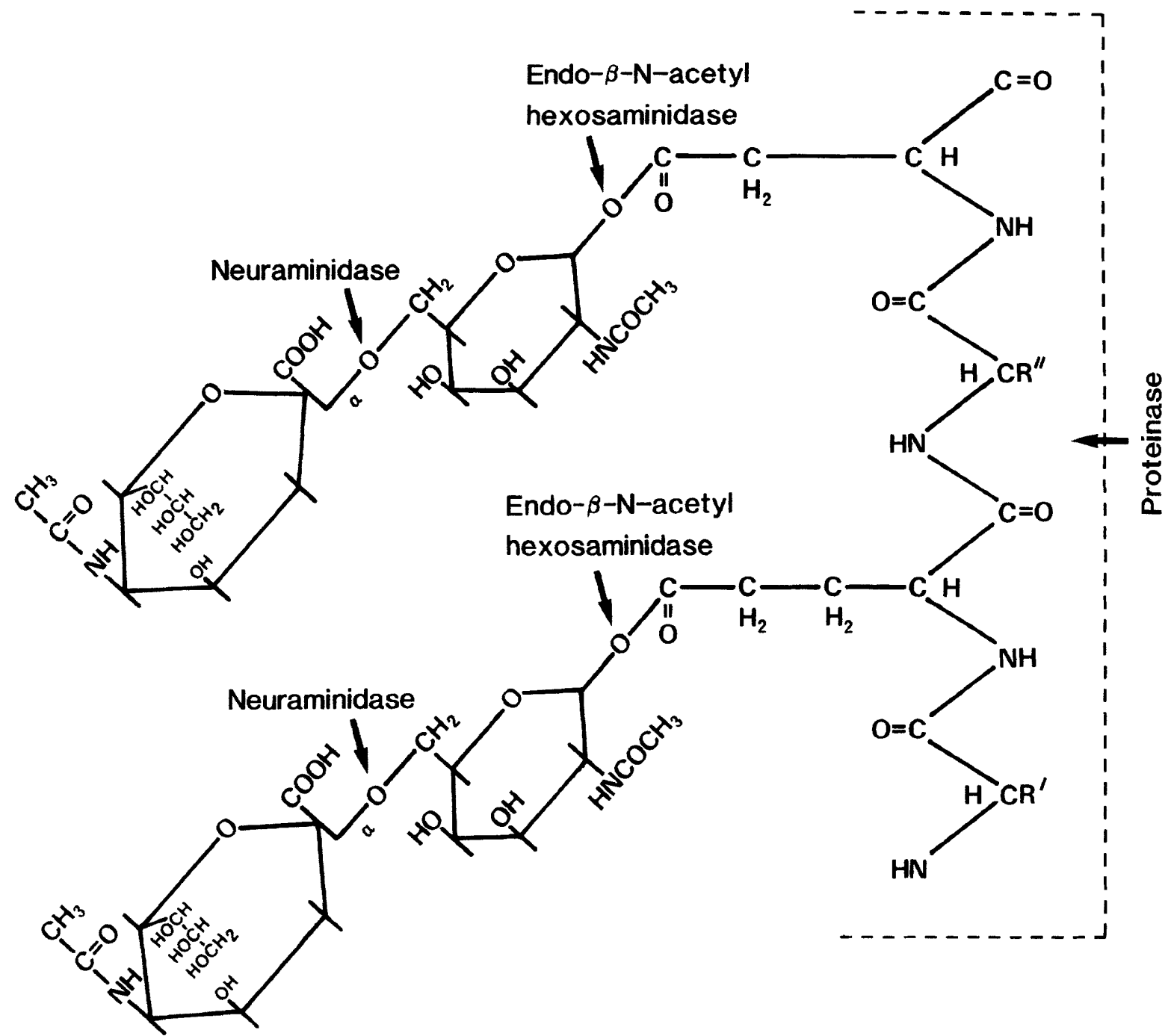

Fig. 3. The structure of bovine sub-maxillary mucin with points of action by $V$. cholerae mucinase complex.

Table. The protein composition and enzymic activities of the partially purified mucinase complex

\begin{tabular}{|c|c|c|c|c|c|c|c|}
\hline \multirow[b]{3}{*}{ Preparation } & \multicolumn{2}{|c|}{ Amount of protein $(\mu \mathrm{g} / \mathrm{ml})$ by } & \multicolumn{5}{|c|}{ Amount of enzyme/mg of microbiuret protein } \\
\hline & \multirow{2}{*}{$\begin{array}{c}\text { Lowry } \\
\text { (as bovine } \\
\text { serum albumin) }\end{array}$} & \multirow{2}{*}{$\begin{array}{c}\text { Microbiuret } \\
\text { (as ovalbumin) }\end{array}$} & \multicolumn{2}{|c|}{$\begin{array}{l}\text { Neuraminidase } \\
\operatorname{lm} U^{*}\end{array}$} & \multirow{2}{*}{$\begin{array}{c}\text { Endoglycosidase } \\
\text { units } \dagger\end{array}$} & \multirow{2}{*}{$\begin{array}{l}\text { Proteinase as } \\
\text { trypsin }(\mu \mathrm{g})\end{array}$} & \multirow{2}{*}{$\begin{array}{c}\text { Phospholipase C } \\
\text { IU } \ddagger\end{array}$} \\
\hline & & & TBA & MPN & & & \\
\hline $\mathrm{G} 100 \mathrm{NI}$ & 562 & 319 & $30 \cdot 0$ & 81 & 0.62 & $51 \cdot 42$ & 0.0014 \\
\hline $\mathrm{G} 100 \cdot \mathrm{N}_{2}$ & 134 & 108 & $55 \cdot 0$ & 346 & $1 \cdot 74$ & $37 \cdot 00$ & 0.0036 \\
\hline G100N3 & 37 & $32 \cdot 8$ & $50 \cdot 0$ & 740 & $4 \cdot 36$ & $56 \cdot 50$ & $0 \cdot 0142$ \\
\hline $\mathrm{G} 100 / \mathrm{N} 4$ & 167 & 136 & $25 \cdot 6$ & 661 & 10.88 & 0 & 0.0035 \\
\hline
\end{tabular}

*One ImU of neuraminidase liberates $0 \cdot 31 \mu \mathrm{g}$ NANA $/ \mathrm{min}:$ TBA = thiobarbituric acid assay; MPN=methoxyphenol neuraminate assay.

$\div$ Calculated relative to the release of glucose from substrate by commercial endoglycosidase.

${ }_{+}^{+}$One IU of phospholipase $C$ hydrolyses $1.0 \mu$ mole of lecithin $(804.2 \mu \mathrm{g}) / \mathrm{min}$. 
activity. Neither the crude methanolic precipitate nor the $\mathrm{G} 100 / \mathrm{N}$ fractions contained cholera enterotoxin in an indirect ELISA assay (Svennerholm and Holmgren, 1978). However, both the methanolic precipitate and the $\mathrm{G} 100 / \mathrm{N}$ preparations showed ADP-ribosylating activity ratios, of 2.14 and 2.00 respectively; this was most likely to be NADase activity which cannot be distinguished from ADP-ribosylation in this particular assay.

\section{Discussion}

Growth of $V$. cholerae in the proteose peptonebovine colostrum medium stimulated good yields of the mucinase complex, containing on average $12.42 \mathrm{IU}$ of neuraminidase/L. After Sephadex G100 partial purification, this yield increased to $43.6 \mathrm{IU} / \mathrm{L}$. As found by other groups interested in the exoenzymes of $V$. cholerae (Schick and Zilg, 1977; Schneider and Parker, 1978 and 1982), it was apparent that a high degree of purification had to be sacrificed in order to maintain high yields of mucinase.

The main difficulty encountered with the use of the colostrum dialysate was the apparently variable induction of enzymes. As shown in the table, the relative amounts of each enzyme in the mucinase complex varied from one preparation to another; this indicated that there was no definite relationship between the enzymes in the complex. However, it was significant that in three of the four G100/N preparations up to $0.5 \% \mathrm{w} / \mathrm{w}$ was proteinase(s). In further studies, to be published separately, these proteinases caused autodigestion of the mucinase complex and it is possible that in this study some of the variable quantitative results were due to this phenomenon. Chien et al. (1975) detected endo- $\beta$ - $\mathrm{N}$-acetylglucosaminidase and proteinase in commercial neuraminidase. The G100/N preparations contained considerable quantities of an endo- $\mathrm{N}$-acetylhexosaminidase which could act on the $\beta$-glycosidic link in the bovine mucin between $\mathrm{N}$-acetylglucosamine and the $\beta$-carboxyl group of aspartic or the $\gamma$-carboxyl group of glutamic acid (fig. 3).

Although not described in detail, the preparations were assayed for the presence of $\mathrm{N}$-acetylneuraminic acid aldolase; no activity was found in any of the G100/N preparations. Ada et al. (1961) warned that this enzyme would interfere with an assay in which neuraminidase activity was measured by the liberation of $\mathrm{N}$-acetylneuraminic acid (NANA) because the aldolase would degrade this to $\mathrm{N}$-acetyl-mannosamine. The difference between the Warren thiobarbituric acid assay and the methoxyphenol-neuraminate assay values for the release of NANA may reflect the availability of neuraminidase-sensitive residues. The submaxillary mucin has some five hundred carbohydrate groups per molecule and it produces a highly viscous solution (Montgomery, 1970) whereas methoxyphenolneuraminate produces a non-viscous solution. Similar problems with the substrate were examined by Fraser and Smith (1975) who showed that a soluble glycoprotein fraction from pooled human plasma was sensitive to $C$. perfringens neuraminidase; the $\alpha_{1}$ acid glycoprotein has an intermediate number of carbohydrate groups per molecule (Montgomery, 1973). One unit of NANA/mg of the glycoprotein was released compared with 0.58 unit/mg with bovine submaxillary mucin (Fraser and Smith, 1975). It does seem worthwhile to propose that in studies of the neuraminidase action on viscous mucin, one of the more sensitive assays containing soluble substrate should be included as a control.

As mentioned above, because of the reported difficulties in separating these $V$. cholerae exoenzymes there is a tendency to group the activities under the term mucinase complex (Burnet and Stone, 1947a; Burnet, 1948, 1949; Jensen, 1953; Singh and Ahuja, 1953; Freter, 1955; Kusama and Craig, 1970; Schneider and Parker, 1982). In the small intestine it is reasonable to propose that these exoenzymes in the complex interact in the breakdown of mucus and adhesion of the organism to the epithelial surface (Schrank and Verwey, 1976; Reed and Williams, 1978; Freter et al., 1978, 1981). Schneider and Parker (1982) proposed several non-exclusive mechanisms for the mucinase. Recently, Ramphal and Pyle (1983) noted that the source of neuraminidase and the chemical nature of the host mucus indicated specificity for certain sialic-acid glycoproteins. The associated enzymic activities in the mucinase complex may be partly responsible for this phenomenon. However, we would agree with Schneider and Parker (1982) that the mucinase complex facilitates $V$. cholerae penetration of the mucus barrier and, in addition, it may attack the glycosidic link between $\mathrm{N}$-acetyl-galactosamine and D-galactose in the monosialoganglioside $G_{M 1}$ and increase the receptivity for $V$. cholerae enterotoxin molecules. The precise role of the neuraminidase is still unsolved. Gascoyne and van Heyningen (1979) and Ackerman et al. (1980) attributed the conversion of membrane gangliosides to enterotoxin-binding gangliosides to the action of neuraminidase, but Holmgren (1981) did not endorse this. However, Vertiev et al. (1981) restated the 
problem of solving this controversy because experimental and commercial preparations of $V$. cholerae neuraminidase are contaminated with other enzymes.

\section{REFERENCES}

Ackerman G A, Wolken K W, Gelder F B 1980 Surface distribution of monosialoganglioside $G_{M 1}$ on human blood cells and the effect of exogenous $G_{M}$ and neuraminidase on cholera toxin surface labeling. A quantitative immunocytochemical study. Journal of Histochemistry and Cytochemistry 28:1100-1112.

Ada G L, French E L, Lind P E 1961 Purification and properties of neuraminidase from Vibrio cholerae. Journal of General Microbiology 24:409 421.

Ames G F 1974 Resolution of bacterial proteins by polyacrylamide gel electrophoresis on slabs. Membrane, soluble and periplasmic fractions. Journal of Biological Chemistry 249: 634644.

Arbuthnott J P. Smyth C J 1979 Bacterial adhesion in host pathogen interactions in animals. In: Ellwood D C et al. (eds) Adhesion of microorganisms to surfaces. Academic Press, London. pp 165-198.

Boehringer 1983 Enzymatic phospholipid analysis. In Biochemica. Boehringer, Mannheim, GmbH. p 17.

Burnet F M 1948 The mucinase of $V$. cholerae. Australian Journal of Experimental Biology and Medical Science 26:71 80.

Burnet F M 1949 Ovomucin as a substrate for the mucinolytic enzymes of $\boldsymbol{V}$. cholerae filtrates. Australian Journal of Biology and Medical Science 27:245 252.

Burnet F M. Stone J D 1947 a Desquamation of intestinal epithelium in vitro by $V$. cholerae filtrates: characterization of mucinase and tissue disintegrating enzymes. Australian Journal of Biology and Medical Science 25:219-226.

Burnet F M, Stone J D $1947 b$ The receptor-destroying enzyme of $V$. cholerae. Australian Journal of Biology and Medical Science 25:227-233.

Chien S. Yevich S J. Li S, Li Y 1975 Presence of endo- $\beta-\mathrm{N}$ acetylglucosaminidase and protease activities in the commercial neuraminidase preparations isolated from Clostridium perfringens. Biochemica Biophysica Research Communications 65:683 691 .

Dubois M, Gilles K A. Hamilton J K. Rebers P A. Smith F 1956 Colorimetric method for determination of sugars and related substances. Analytical Chemistry 28:350-356.

Fraser A G. Smith J K 1975 Preparation of a glycoprotein fraction from pooled human plasma and its evaluation as a substrate for the assay of Clostridium welchii $(C$. perfringens) neuraminidase. Journal of Medical Microbiology 8: 235-249.

Freter R 1955 The serologic character of cholera vibrio mucinase. Journal of Infectious Diseases 97:238 245.

Freter R. Allweiss B, O'Brien P C M, Halstead S A. Macsai M S 1981 Role of chemotaxis in the association of motile bacteria with intestinal mucosa in vitro studies. Infection and Immunity 34:241-249.

Freter R, OBrien P C M. Halstead S A 1978 Adhesion and chemotaxis as determinants of bacterial association with mucosal surfaces. In: McGhee J R el al. (eds) Advances in experimental medicine and biology, vol. 107. Plenum Press. New York, pp 429437.

Gascoyne N, van Heyningen W E 1979 Unmasking of actual
Further studies are being pursued in this laboratory to characterise the individual enzyme components of the mucinase complex and their role in $V$. cholerae pathogenesis.

and potential receptor sites for cholera toxin in intestinal mucosal homogenates. Journal of Infectious Diseases 139: $235-236$

Gottschalk A 1957 Neuraminidase: the specific enzyme of influenza virus and Vibrio cholerae. Biochemica et Biophysica Acta 23:645-646.

Heimer R, Meyer K 1956 Studies on sialic acid of submaxillary mucoid. Proceedings of the National Academy of Sciences USA 42:728-734.

Holmgren J 1981 Actions of cholera toxin and the prevention and treatment of cholera. Nature 292:413-417.

Jensen K E 1953 Immunologic characterization of a mucinolytic enzyme of Vibrio cholerae. Journal of Infectious Diseases 93:107-110.

Kunitz M 1947 Crystalline soybean trypsin inhibitor. II. General properties. Journal of General Physiology 30:291 310.

Kusama H, Craig J P 1970 Production of biologically active substances by two strains of Vibrio cholerae. Infection and Immunity 1:80-87.

Laemmli U K 1970 Cleavage of structural proteins during the assembly of the head of bacteriophage T4. Nature 227:680 685.

Levin R. Brauer R W 1951 The biuret reaction for the determination of proteins-an improved reagent and its application. Journal of Laboratory and Clinical Medicine 38:474. 480.

Lowry O H, Rosebrough N J, Farr A L, Randall R J 1951 Protein measurement with the folin phenol reagent. Journal of Biological Chemistry 193:265-275.

Montgomery R 1970 Glycoproteins. In: Pigman W, Horton D (eds) The carbohydrates, vol 2B, 2nd edn. Academic Press, London, pp 627-709.

Montgomery R 1973 Glycoproteins (including the proteoglycans). In: Aspinall G O (ed) Carbohydrates (Organic Chemistry, series 1, vol 7). Butterworths \& Co, London, pp 213-249.

Palese P, Bucher D, Kilbourne E D 1973 Applications of a synthetic neuraminidase substrate. Applied Microbiology 25: 195-201.

Pangborn M C 1951 A simplified purification of lecithin. Journal of Biological Chemistry 188:471-476.

Ramphal R, Pyle M 1983 Evidence for mucins and sialic acid as receptors for Pseudomonas aeruginosa in the lower respiratory tract. Infection and Immunity 41:339-344.

Reed W P, Williams R C 1978 Bacterial adherence: first step in pathogenesis of certain infections. Journal of Chronic Diseases 31:67-72.

Savage D C 1980 Colonization by and survival of pathogenic bacteria on intestinal mucosal surfaces. In Bitton $G$, Marshall $\mathrm{K}$ (eds) Adsorption of microorganisms to surfaces. John Wiley, Chichester, pp 175-206.

Schick H J, Zilg H 1977 Production and quality control of therapeutically applicable Vibrio cholerae neuraminidase (VCN). In: Griffith A H, Regamey R H (eds) International symposium on biological preparations in the treatment of cancer. (Developments in biological standardization 38). S Karger, Basel, pp 81-85. 
Schneider D R, Parker C D 1978 Isolation and characterization of protease-deficient mutants of Vibrio cholerae. Journal of Infectious Diseases 138:143-151.

Schneider D R, Parker C D 1982. Purification and characterization of the mucinase of Vibrio cholerae. Journal of Infectious Diseases 145:474-482.

Schrank G D, Verwey W F 1976 Distribution of cholera organisms in experimental Vibrio cholerae infections: proposed mechanisms of pathogenesis and antibacterial immunity. Infection and Immunity 13:195-203.

Singh G, Ahuja M L 1953 Observations on the intestinal epithelium desquamating enzyme of vibrios isolated from cholera and non-cholera sources. Indian Journal of Medical Research 41:285-294.

Stewart-Tull D E S, Davies M, Jackson D M 1978 The binding of adjuvant-active mycobacterial peptidoglycolipids and glycopeptides to mammalian membranes and their effect on artificial lipid bilayers. Immunology 34:57-67.

Svennerholm A M, Holmgren J 1978 Identification of Escherichia coli heat-labile enterotoxin by means of a ganglioside immunosorbent assay $\left(\mathrm{G}_{\mathrm{m} 1}\right.$-ELISA) procedure. Current Microbiology 1:19-23.

Tait R M, Nassau P M 1984 Artificial low-molecular-mass substrates of cholera toxin. European Journal of Biochemistry 143:213-219.

Vertiev Y V, Shaginiyan I A, Ezepchuk Y V 1981 Immunoserological characteristics of homogenous choleragen and neuraminidase preparations. Zentralblatt für Bakteriologie Mikrobiologie und Hygiene Abt 1 Orig A 249:235-241.

Warren L 1959 The thiobarbituric acid assay of sialic acids. Journal of Biological Chemistry 234:1971-1975. 